\title{
KARAKTERISTIK BIOAKUSTIK DAN TINGKAH LAKU LUMBA-LUMBA JANTAN HIDUNG BOTOL (Tursiops aduncus)
}

\section{BIOACOUSTIC CHARACTERISTIC AND BEHAVIOUR OF BOTTLE NOSE MALE DOLPHINS (Tursiops aduncus)}

\author{
Muhammad Zainuddin Lubis ${ }^{1}$, Pratiwi Dwi Wulandari ${ }^{2}$, Sri Pujiyati ${ }^{2}$, Totok Hestrianoto ${ }^{2}$ \\ ${ }^{1}$ Program Studi Teknologi Kelautan, Sekolah Pascasarjana, \\ T eknik Geomatika Teknik Informatika, Politeknik Negeri Batam \\ ${ }^{2}$ Depertemen Ilmu dan Teknologi Kelautan, \\ Fakultas Perikanan dan Ilmu Kelautan, Institut Pertanian Bogor \\ Korespondensi: zainuddinlubis@polibatam.ac.id
}

\begin{abstract}
Bioacoustic is the science that combines biology and acoustics are usually refers to research on sound production, dispersion through elastic media, and reception in animals, including humans. This study observed the behavior male dolphins by doing science approach bioakustik who viewed the characteristics of these dolphins. Male dolphins (Tursiops aduncus) that maintained at Taman Safari Indonesia, Cisarua Bogor has the lowest intensity value amounting to 28.03 $\mathrm{dB}$ and the highest amounted to $32.01 \mathrm{~dB}$. Average parameters is measurable salinity of $30 \mathrm{ppm}$ and a temperature of $23{ }^{\circ} \mathrm{C}$ with the depth of the pool is 4.5 meter. Range frequency clicking sound with the highest intensity value that is equal to $32 \mathrm{~dB}$ with a clicking sound 3 after dinner on day 2 contained in the frequency range ie 1400-1600 Hz. Click sound frequency range of male dolphins (Tursiop aduncus) in Taman Safari have frequency 1400- $1500 \mathrm{~Hz}$.
\end{abstract}

Keyword: bioacoustic, bottle nose male dolphins (Tursiops aduncus), frequency, intensity

\begin{abstract}
ABSTRAK
Bioakustik adalah ilmu yang menggabungkan biologi dan akustik yang biasanya merujuk pada penelitian mengenai produksi suara, dispersi melalui media elastis, dan penerimaan pada hewan, termasuk manusia. Penelitian ini mengamati tingkah laku lumba-lumba jantan dengan melakukan pendekatan ilmu bioakustik yang melihat karakteristik dari lumba-lumba tersebut. Lumba-lumba jantan (Tursiops aduncus) yang dipelihara di Taman Safari Indonesia, Cisarua Bogor memiliki nilai intensitas terendah sebesar $28.03 \mathrm{~dB}$ dan tertinggi adalah sebesar $32.01 \mathrm{~dB}$. Rata-rata parameter yang terukur yaitu salinitas sebesar 30 ppm dan suhu $23{ }^{\circ} \mathrm{C}$ dengan kedalaman kolam 4,5 meter. Range frekuensi suara klik dengan nilai intensitas tertinggi yaitu sebesar 32 dB dengan suara klik 3 sesudah makan pada hari ke 2 yang terdapat pada range frekuensi yaitu 1400-1600 Hz. Range frekuensi suara klik lumba-lumba jantan (Tursiop aduncus) di Taman Safari yaitu pada frekuensi 1400- $1500 \mathrm{~Hz}$.
\end{abstract}

Kata kunci: bioakustik, frekuensi, intensitas, lumba-lumba jantan hidung botol (Tursiop saduncus) 


\section{PENDAHULUAN}

\section{Latar belakang}

Lumba-lumba hidung botol (Bottlenose dolphin) adalah mamalia laut yang bernafas dengan paru-paru. Lubang pernafasan external sebagai satu satunya lubang respirasi disebut sebagai blowhole yang berlokasi di dekat apex dari tulang tengkorak (Rommel \& Lowenstine 2001). Lumba-lumba memiliki beberapa kantong udara (air sac) sebelum masuk ke internal nares. Kantong udara ini berfungsi untuk menampung sementara nitrogen saat hewan menyelam yang akan dikeluarkan saat ekspirasi (Marshall 2002). Gambaran organ dalam dan saluran pernafasan dari blowhole sampai paru-paru Lumba-lumba hidung botol (bottlenose dolphin) dapat dilihat pada Gambar 1.

Gambar 1 adalah gambaran organ dalam dan saluran pernafasan dari blowhole sampai paru-paru Lumba-lumba hidung botol (bottlenose dolphin) (Marshall 2002). Lumba-lumba dapat bertahan menyelam dalam waktu lama karena beberapa sebab, yaitu: (1) kemampuan menyimpan udara pada paru-paru sangat tinggi (75\%); (2) denyut jantung dapat menurun dari $100 \mathrm{kali}$ per menit menjadi 10 kali per menit untuk memelihara oksigen; (3) kemampuannya menarik darah yang kaya oksigen dari otot ke dalam organ untuk menjaga kadar oksigen dan mencegah gangguan karena kadar nitrogen yang tinggi ketika secara cepat ke permukaan dari penyelaman yang dalam. Lumba-lumba menyimpan oksigen dalam darah sebagai hemoglobin dan otot sebagai mioglobin sehingga dapat secara mudah digunakan saat diperlukan selama respirasi sel (Marshall 2002).

Caldwells mengamati bahwa lumbalumba yang terisolasi, ataupun yang sedang menjadi tawanan dilakukan pelatihan peluit dengan individual. Grafik frekuensi terlihat berbeda, atau pola perubahan frekuensi dari waktu ke waktu, dan hipotesis bahwa peluit ini digunakan untuk mengirimkan informasi identitas (Caldwell \& Caldwell 1965, Caldwell et al. 1990). Beberapa penelitian telah mendokumentasikan tentang peluit tanda tangan di berbagai konteks, termasuk berenang bebas pada lumba-lumba mati (Janik \& Slater, 1998; Esch et al. 2009), secara singkat menahan lumba-lumba liar (Sayigh et al. 2007, Watwood et al. 2005), dan bebas mulai lumba-lumba liar (misalnya, Watwood 2003, Buckstaff 2004, Cook et al.
2004; Watwood et al. 2004, 2005). Adapun macam suara yang dihasilkan oleh lumbalumba yang telah dikategorikan ke dalam (1) klik broad-band ekolokasi digunakan untuk memantau lingkungan, mangsa dan predator deteksi mereka, (2) pita siaran meledak-berdenyut dan (3) suara tonal (sering disebut peluit) yang digunakan untuk komunikasi (Cook et al. 2004).

Lumba-lumba hidung botol termasuk jenis mamalia yang memiliki kepekaan pendengaran yang baik. Hal itu disebabkan oleh sistem jaringan indera pendengarannya telah terbangun dengan baik. Lumba-lumba dapat mendengar suara dengan frekuensi $1-150 \mathrm{kHz}$. Sensitivitas yang tinggi ini sangat diperlukan untuk echolocation. Echolocation merupakan kemampuan untuk mengindera melalui suara dan pendengaran. Aktivitas ini terjadi melalui dua tahap, yaitu yang pertama Lumba-lumba mengeluarkan Clicks berfrekuensi tinggi $(120 \mathrm{kHz})$, kemudian diproyeksikan melalui daerah bagian depan kepala (melon) ke media air sekitarnya. Ketika Clicks mengenai suatu objek, akan terbentuk gema atau gelombang suara yang akan diterima oleh lumba-lumba dan diproses menjadi informasi tentang lopkasi atau jenis objek (Dolphin Institute 2002).

Suara klik umumnya digunakan untuk tujuan ekolokasi, sementara suara ledakanberdenyut dan peluit memainkan peran utama dalam komunikasi internal dan antar kelompok (Azzolin et al. 2013). Peluit yang terus menerus, memberikan sinyal frekuensi (Papale et al. 2013), dengan berbagai lebar pancaran $800 \mathrm{~Hz}$ dan 28,5 kHz (Janik 2009) sering terdapat komponen harmonik (Papale et al. 2013). Seekor lumba-lumba memulai interaksi dengan pemberian sinyal, dengan informasi, dalam pita frekuensi tertentu. Sumber sinyal kemudian bergantung pada sumber untuk mendengar dan bereaksi terhadap suara. Pendengaran pada Lumbalumba berkisar dari sekitar $50 \mathrm{~Hz}-150 \mathrm{kHz}$, dengan variasi tambahan di antara spesies (Janik 2009).

Kingdom : Animalia

Filum : Chordata

Subfilum : Vertebrata

Kelas : Mamalia

Ordo : Cetacea

Subordo : Odonticeti

Famili : Delphinidae

Genus : Tursiops

Spesies : T. Anduncus

Lumba-lumba hidung botol (Tursiops aduncus) pada suatu perairan dapat dilihat 
pada Gambar 2.

Bioakustik adalah ilmu yang menggabungkan biologi dan akustik yang biasanya merujuk pada penelitian mengenai produksi suara, dispersi melalui media elastis, dan penerimaan pada hewan, termasuk manusia. Hal ini melibatkan neurofisiologi dan anatomi untuk produksi dan deteksi suara, serta hubungan sinyal akustik dengan medium dispersinya. Temuan pada bidang ini memberikan bukti bagi kita tentang evolusi mekanisme akustik, dan dari sana, evolusi hewan yang menggunakannya (Simmonds dan MacLennan 2005). Tetapi karena ilmu akustik sangat berkembang pada lumba-lumba, peneliti sebelumnya telah menekankan rekaman dan analisis vokalisasi (Evans 1966; Herman \& Tavolga 1980; Norris 1969; Popper 1980; Watkins \& Wartzok 1985).

Nilai tekanan noise biasanya dinyatakan dalam bentuk decibels (dB) dengan frekuensi level noise sebesar 1 dyne $/ \mathrm{cm} 2 \quad[=1 \mu \mathrm{B}$ (microbar) $]$. Tingkat noise bernilai sekitar $15 \mathrm{~dB}$ dibawah nilai refrensi level noise. Nilai level yang digunakan secara global sebagai referensi dalam medium air adalah $1 \mu \mathrm{B}(0 \mathrm{~dB}=1 \mu \mathrm{B}=$ 1 dyne/cm2) (Tavolga 1971). Penelitian bioakustik ini dibutuhkan untuk dapat mengetahui bahasa komunikasi (Acoustic communication) pada mamalia. Bioakustik tidak lepas dari penggunaan overfishing sebagai alat perekam suara dimana tekanan akustik direkam pada hidrofon adalah sumber waktu gangguan tekanan pada laut $(\Delta \mathrm{P})$ yang relatif terhadap tekanan latar belakang laut di kedalaman perekaman pada medium air. Kelebihan tekanan suara dilaut biasanya bernilai kecil ( 10-2 $\mathrm{Pa})$, dan itu telah menjadi standar di laut pada literatur akustik untuk menampilkan tekanan suara di daftar skala desibel (dB) relatif terhadap referensi tekanan (Po) dari 1 $\mu \mathrm{Pa}$ (Urick 1975). Selain itu, konvensi untuk menggunakan $1 \mathrm{~m}$ sebagai jarak referensi (ro) yaitu pada saat menghitung tekanan akustik dari sumber datangnya suara.

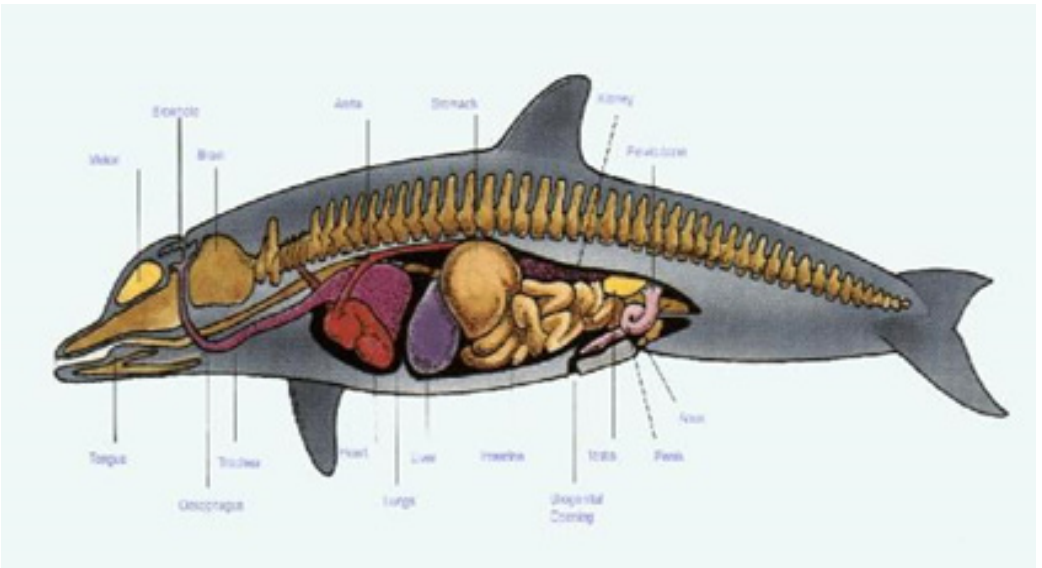

Gambar 1. Gambaran organ dalam dan saluran pernafasan dari blowhole sampai paru-paru



Gambar 2. Lumba-lumba hidung botol 
Tujuan dari kegiatan penelitian ini adalah sebagai berikut. Menjelaskan karakteristik dan membedakan karakteristik suara lumba-lumba jantan hidung botol (Tursiops aduncus) pada kolam fisioterapi, karantina, dan show dengan menggunakan metode bioakustik. Melihat tingkah laku lumbalumba jantan hidung botol (Tursiops aduncus).

\section{METODE PENELITIAN}

Kegiatan penelitian dilaksanakan pada bulan Maret hingga September 2015. Kegiatan pengambilan data dilaksanakan di Taman Safari Indonesia, Cisarua Bogor. Peta lokasi penelitian Taman Safari Indonesia, Cisarua dapat dilihat pada Gambar 3.

Adapun alat dan bahan yang digunakan dalam metode penelitian dapat dilihat pada Tabel 1 .

Alat yang digunakan pada penelitian ini adalah akuarium kaca, Styrofoam, aerator, hidrofon SQ03, Termometer $\mathrm{Hg}$ untuk mengukur suhu air ; Refraktometer untuk mengukur salinitas air yang ada didalam kolam; Dolphin EAR 100 hydrophone nomor seri DE989505 yang merupakan sensor suara; kamera underwater Gopro hero 3+yang berfungsi untuk merekam pergerakan pada lumba-lumba secara visual. Perangkat lunak Matlab (www.mathworks.com) dan Wavelab (www.steinberg.net) yang digunakan untuk mengolah data; dan PC yang digunakan sebagai media penyimpanan langsung dan pengolahan data suara yang terekam.

Bahan yang digunakan adalah 4 ekor lumba-lumba jantan hidung botol (Tursiops aduncus) pada kolam karantina, taman safari Indonesia; Gambar 4 adalah satu set alat perekam suara, sedangkan Gambar 5 adalah diagram alir penelitian.

Sketsa penelitian lumba-lumba jantan hidung botol (Tursiops aduncus) pada saat di penangkaran/ kolam karantina dapat dilihat pada Gambar 6. Instrumen/ alat yang digunakan pada sketsa yaitu Gopro hero3+ sebagai kamera bawah air yang merekam secara visual.

\section{Parameter lingkungan}

Parameter lingkungan yang diukur adalah suhu dan salinitas karena kedua parameter fisika ini merupakan faktor yang paling berpengaruh terhadap tingkat stress ikan. Stres yang dialami lumba-lumba dapat menyebabkan penyimpangan tingkah laku pada lumba-lumba.

Pengukuran suhu air dalam akuarium dilakukan dengan cara memasukkan termometer $\mathrm{Hg}$ kedalam akuarium. Termometer dikibas-kibaskan sebelum dimasukkan kedalam air untuk memperkecil efek muainya dan mengembalikan titik awal termometer sebelum pengukuran dimulai. Suhu air diperoleh dengan membaca skala yang ditunjukkan pada termometer Hg.

Salinitas diukur menggunakan refraktometer cara dengan meneteskan sampel air akuarium sebanyak satu tetes air ke atas permukaan kaca refraktometer lalu ditutup. Nilai salinitas didapat dengan membaca skala yang ditunjukkan pada teropong refraktometer. Pencatatan salinitas dilakukan pembulatan keatas tanpa desimal.

\section{Pengambilan video pergerakan pada lumba-lumba}

Pengambilan video dengan menggunkan kamera hero3+ pada lumbalumba berfungsi untuk melihat luasan atau sudut dari pancaran pixel dari kamera. Adapun gambar ilustrasi dapat dilihat pada Gambar 7.

Gambar 7 menjelaskan sketsa pengambilan video menggunakan 1 kamera Gopro hero3+ yang merekam dengan posisi berada diatas dan menggunakan 1 sudut atau 1 titik pengambilan video Pengamatan/ pengambilan video ini dilakukan dengan merekam pada : a. sebelum makan, b. sesudah makan. Karakter pada Lumbalumba Jantan yang dilihat yaitu Aktivitas pergerakan, dan Aktivitas bersuara dengan durasi sebanyak \pm 5 menit. 


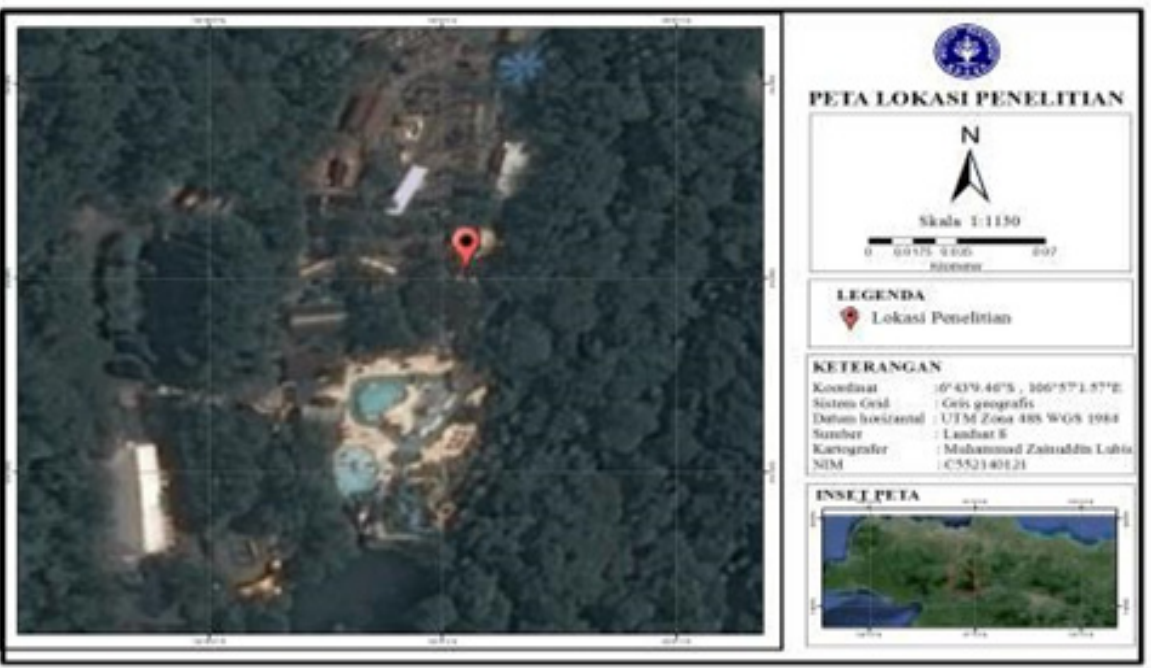

Gambar 3. Peta lokasi penelitian Taman Safari Indonesia, Cisarua Bogor

Tabel 1. Alat dan bahan penelitian

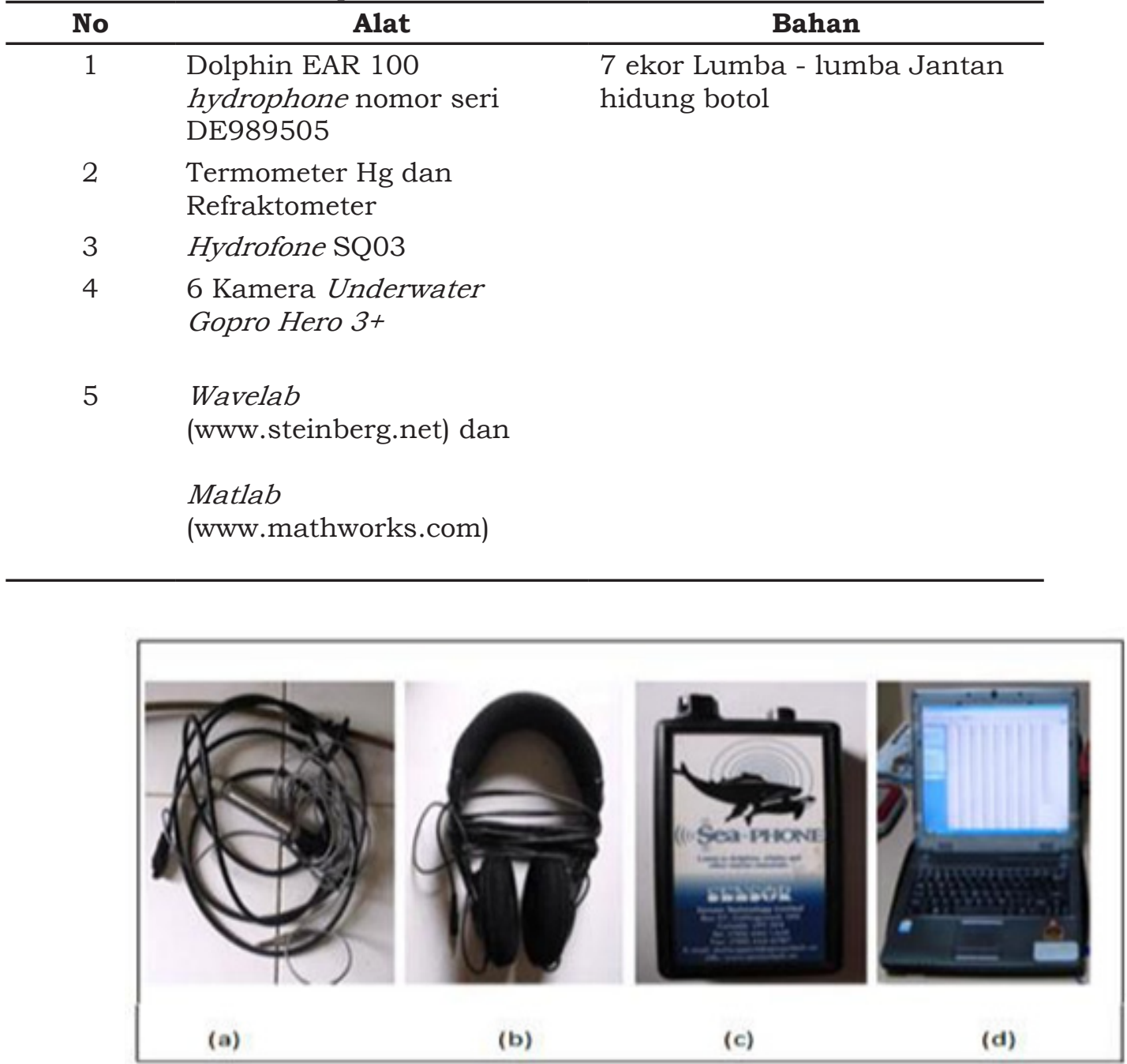

Gambar 4. Set alat perekam suara, (a) Hidrofon, (b) Headphone, (c) catu daya/baterai, dan (d) laptop untuk data logging dan data processing 


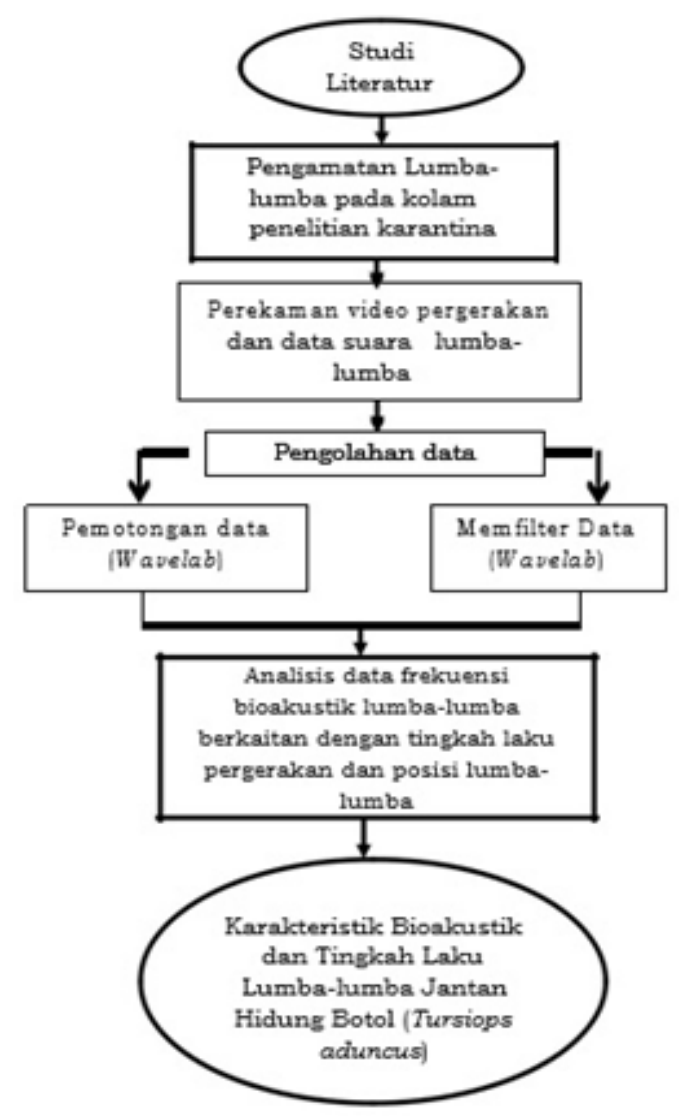

Gambar 5. Diagram alir penelitian

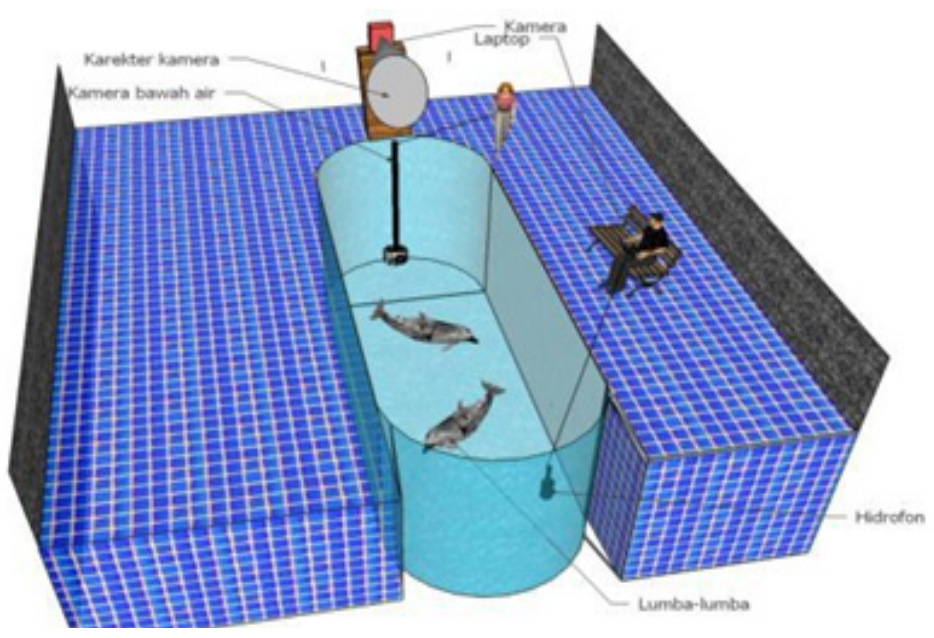

Gambar 6. Sketsa penelitian lumba-lumba jantan hidung botol (Tursiops aduncus) pada saat di penangkaran/kolam karantina 


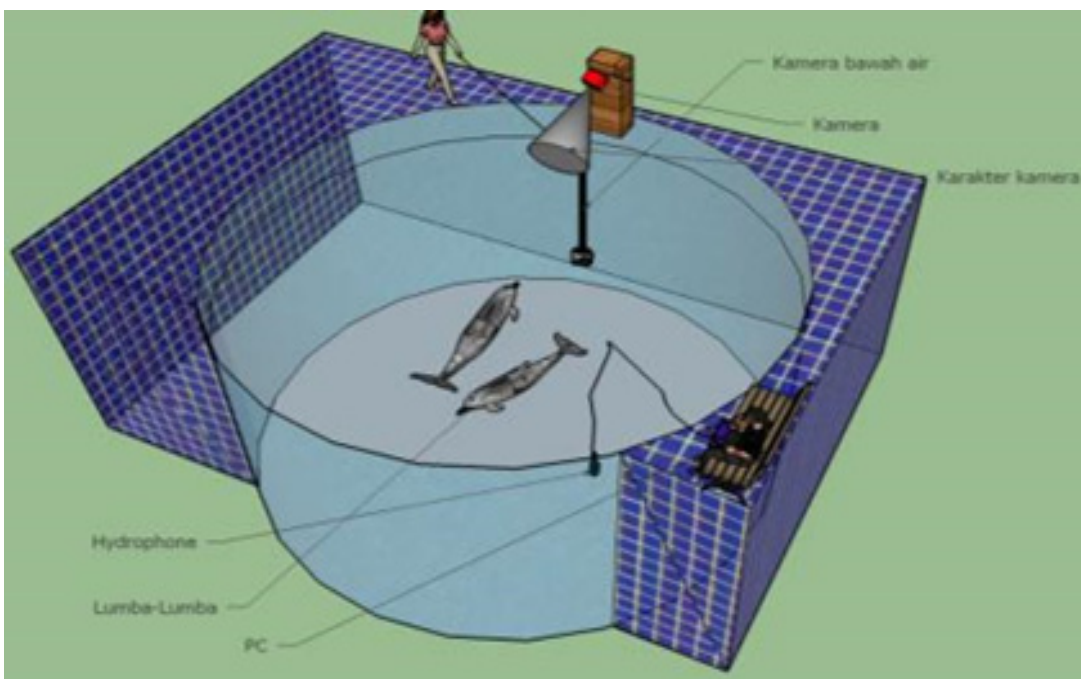

Gambar 7. Sketsa penampakan karakter kamera dari atas

\section{HASIL DAN PEMBAHASAN}

Proses perekeman suara lumba-lumba dilakukan sebanyak 3 kali pengambilan data dengan tanggal dan minggu yang berbeda. Proses penelitian ini tidak luput dari pengambilan parameter terukur yaitu mengukur parameter suhu dan salinitas yang ada pada kolam penelitian yaitu kolam karantina dengan hasil salinitas dan suhu yang diperoleh dapat dilihat pada Tabel 2 .

Dari Tabel 2 terlihat tabel salinitas dan suhu sebelum dan sesudah pada kolam karantina lumba-lumba jantan dengan pengukuran parameter tersebut yaitu pada hari ke 1, 2 , dan 3 pada kolam karantina dengan waktu pengambilan yaitu sebelum dan sesudah lumba-lumba makan. Sebelum makan dilakukan pengambilan data yang menunjukkan besarnya nilai salinitas yaitu $30 \mathrm{ppm}$, sedangkan pengambilan data sesudah makan salinitas mengalami penurunan menjadi $29 \mathrm{ppm}$ hal ini menyebabkan salinitas yang terdapat pada kolam karantina sudah terkompinasi dengan faktor-faktor yang ada disekitar Begitu juga dengan hari kedua dengan salinitas sebesar 28 ppm pada saat sebelum makan dan $27 \mathrm{ppm}$ sesudah makan dengan suhu sebelum makan $23{ }^{\circ} \mathrm{C}$ dan sesudah makan yaitu sebesar $22^{\circ} \mathrm{C}$.

\section{Karakteristik suara lumba-lumba}

Suara merupakan hal yang sangat penting terhadap tingkah laku saat berkomunikasi untuk beberapa jenis ikan dan menurut Pratt (1998) Ikan dapat mengeluarkan beragam amplitude suara untuk melakukan komunikasi dalam pertukaran informasi. Informasi yang dibawa dari sinyal-sinyal suara menjelaskan mengenai keadaan bahaya yang mengancam, keadaan agresif untuk menakuti musuh, atau panggilan peminangan. Suara juga dihasilkan dari dampak tingkah laku lainnya seperti saat makan, bergerak, menghindari musuh, dan reproduksi (seksualitas dan fase pembesaran) (Popper and Plat 1993). Hasil dari penelitian ini berupa data suara yang berasal dari perangkat lunak wavelab dan dilakukan anti log lalu diolah dengan menggunakan perangkat lunak matlab sehingga menghasilkan grafik intensitas suara terhadap frekuensi. Frekuensi yang direkam yaitu 5.200 - $22.000 \mathrm{~Hz}$. Data yang ditampilkan pada grafik yaitu ping 62 hingga ping 195. Berikut ini ditampikan empat grafik hubungan Antara frekuensi dengan intensitas yaitu grafik klik1,2,3, dan 4 pada hari ke 1 penelitian dengan frekuensi lumba-lumba yang berbeda-beda saat sebelum makan (Gambar 8), grafik hari ke 1 pada saat sebelum makan (Gambar 9).

Berdasarkan Gambar 8 frekuensi yang berada pada nilai maksimum yaitu sebesar 22.000 Hz. Pada data frekuensi klik 1 lumba lumba jantan kolam karantina di tunjukan garis berwarna merah. Data frekuensi klik 2 lumba lumba jantan pada kolam karantina berwarna biru. Data frekuensi klik 3 lumba lumba jantan pada kolam karantina berwarna hijau sedangkan data frekuensi klik 4 lumba-lumba jantan pada kolam karantina berwarna kuning. Peningkatan suara kembali yaitu pada frekuensi $1.400-1.500 \mathrm{~Hz}$ dengan nilai intensitas $28 \mathrm{~dB}$ dan terendah yaitu $22 \mathrm{~dB}$ dengan kisaran frekuensi berada pada detik ke 75 dari total setiap panjang suara yaitu 
90 detik. Intensitas tertinggi berada pada intensitas awal yang terdapat pada waktu yaitu berkisar 0-10 detik dari data suara yang dihasilkan, Dan intensitas yang paling rendah terdapat pada lumba lumba klik 4 yaitu $21 \mathrm{~dB}$. Hal ini mungkin disebabkan karena lumba-lumba masih dalam proses pengenalan dengan alat yaitu hidrofon.

Berdasarkan Gambar 9 yang merupakan grafik hubungan frekuensi terhadap intensitas lumba-lumba jantan sesudah makan pada hari ke 1 dengan maksimum frekuensi $22000 \mathrm{~Hz}$. Klik 1 memiliki intensitas $26 \mathrm{~dB}$ dan pada intensitas akhir adalah 19 dB. Sedangkan pada suara lumba lumba klik 2 memiliki intensitas awal $24 \mathrm{~dB}$ dan intensitas akhir $18 \mathrm{~dB}$. Pada klik 4 intensitas awal memiliki $22 \mathrm{~dB}$ dan intensitas akhir memiliki $18 \mathrm{~dB}$. Intensitas awal yang lebih tinggi $27 \mathrm{~dB}$ dan intensitas awal yang rendah pada klik 4 yaitu $22 \mathrm{~dB}$ dan mengalami peningkatan hampir sama dengan gambar sebelumnya yaitu pada data suara klik 1 dengan warna merah sebesar $21 \mathrm{~dB}$ dan warna hijau yaitu suara klik ke 3 dengan intensitas sebesar $20.8 \mathrm{~dB}$. Grafik hubungan frekuensi dengan intensitas pada hari ke 2 sebelum makan dapat dilihat pada Gambar 10.

Pada Intensitas awal klik 1 memiliki intensitas sebesar $26 \mathrm{~dB}$ dan pada intensitas akhir adalah $23 \mathrm{~dB}$. Sedangkan pada suara lumba lumba klik 2 memiliki intensitas awal $24 \mathrm{~dB}$. Intensitas akhir $18 \mathrm{db}$, dan pada suara lumba-lumba klik 3 memiliki intensitas awal $23 \mathrm{db}$ Sedangkan nilai akhir yaitu $18 \mathrm{db}$. Pada klik 4 nilai intensitas awal memiliki nilai $22 \mathrm{db}$ dan intensitas akhir memiliki $18 \mathrm{db}$. Dapat kita lihat pada intensitas lumba-lumba klik 1 memiliki intensitas awal yang lebih tinggi yaitu $27 \mathrm{db}$ dan intensitas awal yang rendah pada klik 4 yaitu 22db. Grafik hubungan frekuensi dengan intensitas pada hari ke 2 sesudah makan hari ke 2 dapat dilihat pada Gambar 11 .

Berdasarkan grafik sesudah makan pada kolam karantina pada hari ke 2 dengan maksimum frekuensi $22.000 \mathrm{hz}$. Pada Intensitas awal pada lumba lumba klik 1 memiliki intensitas $26 \mathrm{~dB}$ dan intensitas akhir adalah $23 \mathrm{~dB}$. Sedangkan pada suara lumba lumba klik 2 memiliki intensitas awal $24 \mathrm{~dB}$ dan intensitas akhir $18 \mathrm{~dB}$. Pada suara lumba lumba klik 3 memiliki intensitas awal $23 \mathrm{~dB}$ dan akhir $18 \mathrm{~dB}$ dengan nilai intensitas tertinggi dan tetap pada frekuensi 1.400-1.440 pada detik ke 75 . Pada klik 4 intensitas awal memiliki $22 \mathrm{~dB}$ dan intensitas akhir memiliki $18 \mathrm{~dB}$. Dapat kita lihat pada intensitas lumba-lumba klik 1 memiliki intensitas awal yang lebih tinggi $27 \mathrm{~dB}$ dan intensitas awal yang rendah pada klik 4 yaitu 22dB. Grafik hubungan frekuensi dengan intensitas pada hari ke 3 sebelum makan hari ke 2 dapat dilihat pada Gambar 12 .

Berdasarkan grafik di atas merupakan grafik hubungan frekuensi terhadap intensitas lumba-lumba jantan sebelum makan pada hari ke 3 dengan maksimum frekuensi $22.000 \mathrm{~Hz}$. Pada data frekuensi klik 1 lumba lumba jantan pada kolam karantina di tunjukan oleh grafik berwarna merah. Data frekuensi klik 2 lumba lumba jantan pada kolam karantina berwarna biru. Data frekuensi klik 3 lumba lumba jantan pada kolam karantina berwarna hijau sedangkan data frekuensi klik 4 lumba-lumba jantan pada kolam karantina berwarna kuning. Berdasarkan grafik yang di tunjukan pada gambar di atas intensitas awal suara lumbalumba pada klik 1 memiliki $25 \mathrm{~dB}$ dan intensitas akhir $23 \mathrm{~dB}$, sedangkan pada klik 2 suara lumba-lumba memiliki intensitas awal dan intensitas akhir sama yaitu $24 \mathrm{~dB}$. Pada klik 3 memiliki intensitas awal dan akhir sama yaitu $25 \mathrm{~dB}$. Dan klik 4 suara lumba-lumba memiliki intensitas awal 25 $\mathrm{dB}$ dan intensitas akhir $24 \mathrm{~dB}$. Dapat kita lihat pada intensitas lumba-lumba klik 1 memiliki intensitas awal yang lebih tinggi $25 \mathrm{~dB}$. Grafik hubungan frekuensi dengan intensitas pada hari ke 3 sesudah makan hari ke 2 dapat dilihat pada Gambar 13.

Berdasarkan grafik di atas merupakan grafik hubungan frekuensi terhadap intensitas lumba-lumba jantan sesudah makan pada hari ke 3 dengan maksimum frekuensi $22000 \mathrm{~Hz}$. Pada data frekuensi klik 1 lumba lumba jantan pada kolam karantina di tunjukan oleh grafik berwarna merah. Data frekuensi klik 2 lumba lumba jantan pada kolam karantina berwarna biru. Data frekuensi klik 3 lumba lumba jantan pada kolam karantina berwarna hijau sedangkan data frekuensi klik 4 lumba-lumba jantan pada kolam karantina berwarna kuning. Berdasarkan grafik yang di tunjukan pada gambar di atas intensitas awal suara lumbalumba pada klik 1 memiliki $23 \mathrm{~dB}$ dan intensitas akhir $24 \mathrm{~dB}$, sedangkan pada klik 2 suara lumba-lumba memiliki intensitas awal dan intensitas akhir sama yaitu 24 dB. Grafik gabungan hubungan frekuensi dengan intensitas pada hari ke 1, 2, dan 3 dengan sesudah makan hari ke 2 dan ke 3 sesudah makan hari ke 2 dapat dilihat pada Gambar 14. 
Berdasarkan grafik di atas merupakan grafik hubungan frekuensi terhadap intensitas lumba-lumba jantan sebelum dan sesudah makan dengan maksimum frekuensi $22.000 \mathrm{~Hz}$. Pada data frekuensi lumba lumba jantan pada kolam karantina sebelum makan hari ke 1 di tunjukan oleh grafik berwarna merah. Data frekuensi klik lumba lumba jantan pada kolam karantina sebelum makan hari ke 2 berwarna biru. Data frekuensi klik lumba-lumba jantan pada kolam karantina sebelum makan hari ke 3 diberi warna hijau. Data frekuensi klik lumba-lumba jantan pada kolam karantina sesudah makan hari ke 2 di tandai dengan warna hitam. Dan data frekuensi klik lumbalumba pada kolam karantina sesudah makan hari ke 3 di beri warna kuning. NIlai intensitas tertinggi diperoleh oleh garis berwarna hijau dan kuning yaitu sebelum makan hari ke 3 dan sesudah makan hari ke 3 dengan nilai intensitas sebesar $30 \mathrm{~dB}$ pada range frekuensi yaitu $1.420-1.460 \mathrm{~Hz}$ pada range waktu yaitu sekitar detik ke 70-75.

Tabel 2. Salinitas dan suhu sebelum dan sesudah makan

\begin{tabular}{|cccccc|}
\hline \multirow{2}{*}{ Hari Ke } & Tanggal & $\begin{array}{c}\text { Salinitas } \\
(\%)\end{array}$ & $\begin{array}{c}\text { Salinitas } \\
(\%)\end{array}$ & \multicolumn{2}{c|}{ Suhu ${ }^{\circ} \mathrm{C}$} \\
\cline { 2 - 6 } & Sebelum & Sesudah & Sebelum & Sesudah \\
\hline 1 & $\begin{array}{c}6 \mathrm{Mei} \\
2015\end{array}$ & 30 & 29 & 22 & 22 \\
2 & $\begin{array}{c}13 \mathrm{Mei} \\
2015\end{array}$ & 28 & 27 & 23 & 22 \\
3 & $\begin{array}{c}20 \mathrm{Mei} \\
2015\end{array}$ & 31 & 30 & 25 & 24 \\
\hline
\end{tabular}

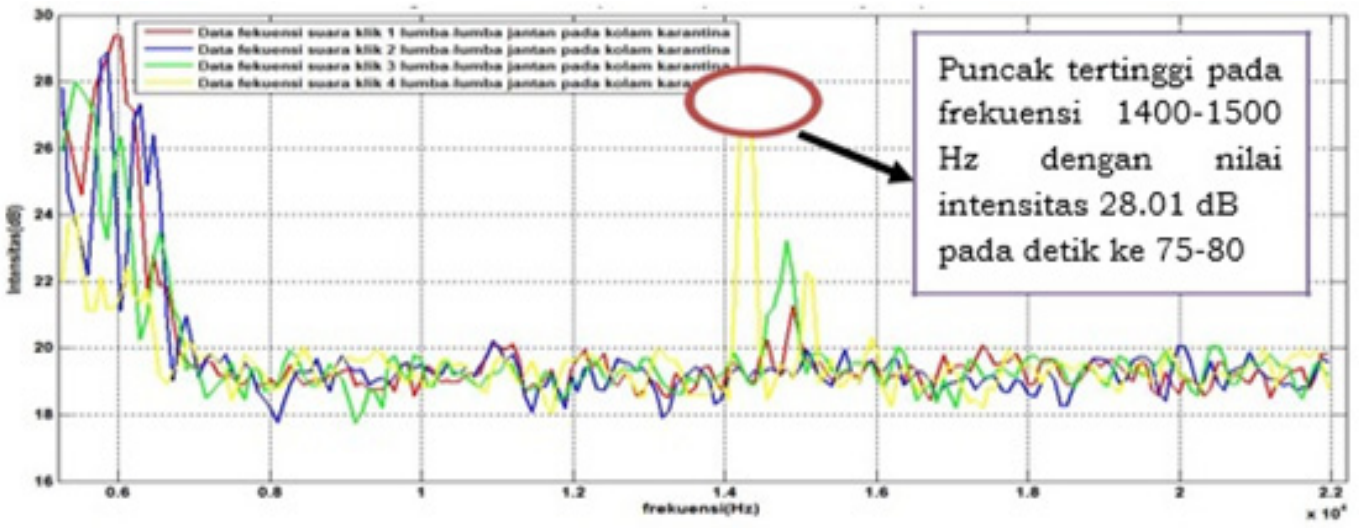

Gambar 8. Hubungan frekuensi terhadap intensitas sebelum makan hari ke 1 


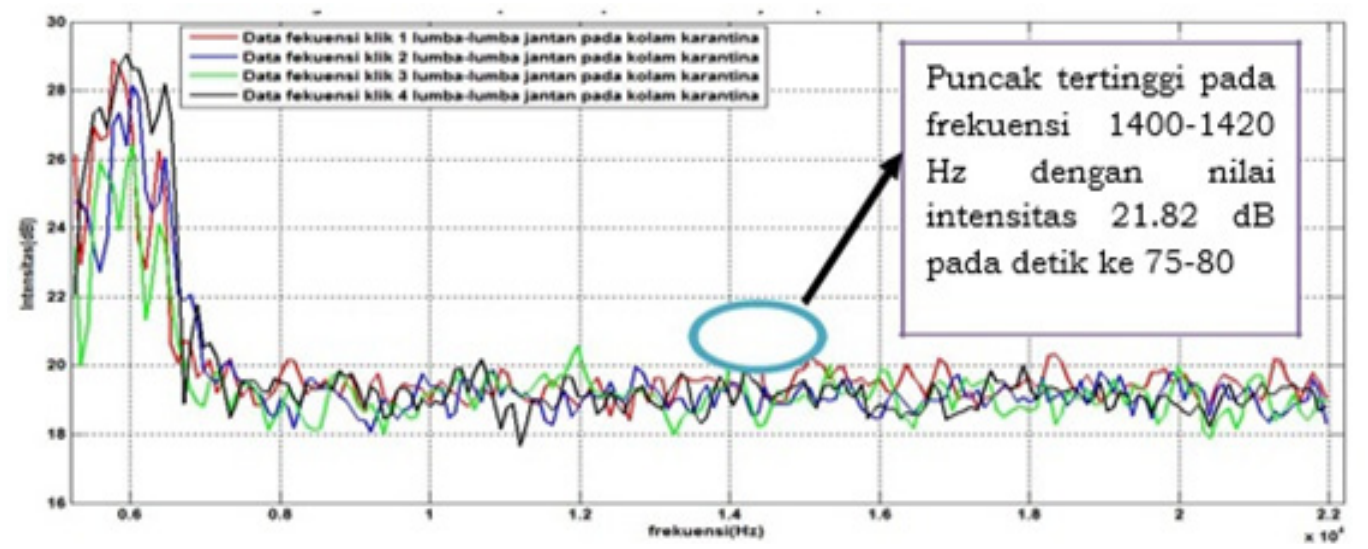

Gambar 9. Hubungan frekuensi terhadap intensitas sesudah makan hari ke 1

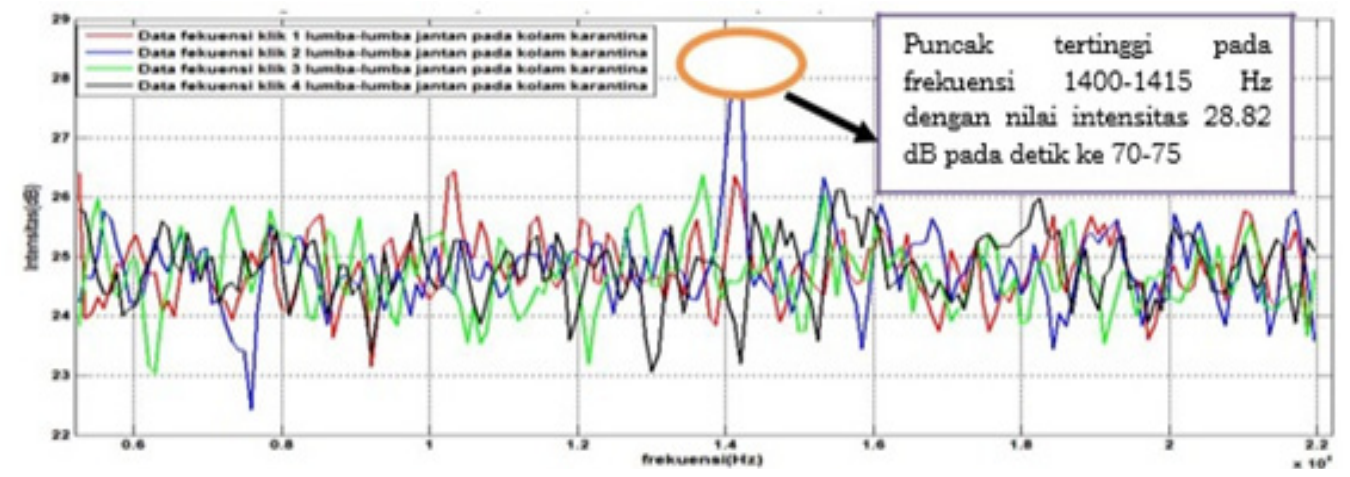

Gambar 10. Hubungan frekuensi terhadap intensitas sebelum makan hari ke 2

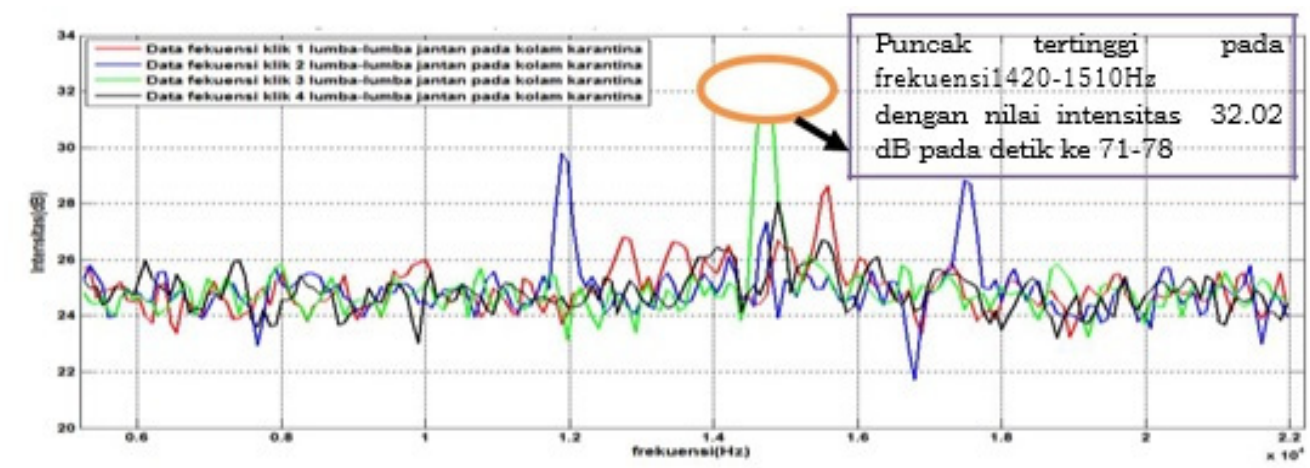

Gambar 11. Hubungan frekuensi terhadap intensitas sesudah makan hari ke 2

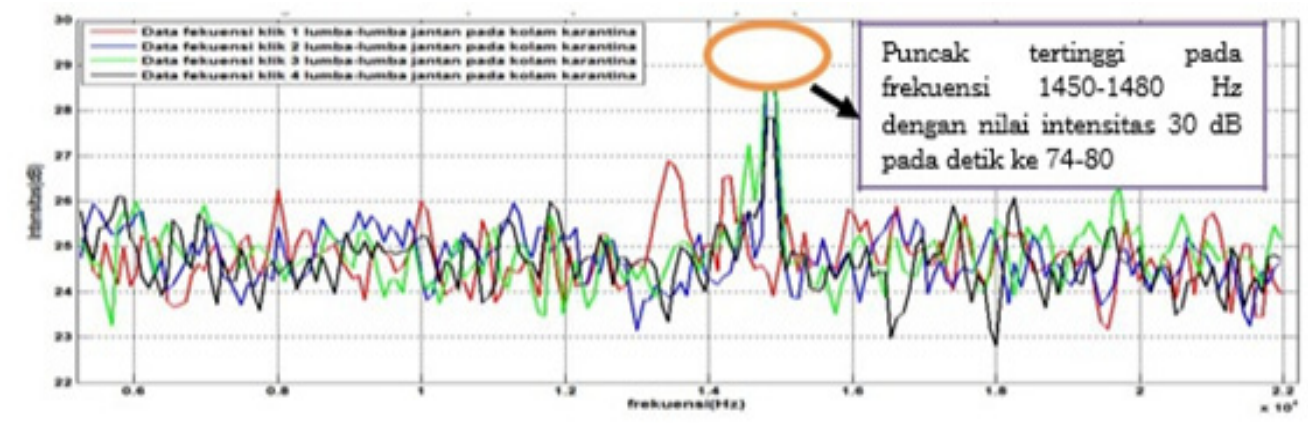

Gambar 12. Hubungan frekuensi terhadap intensitas sebelum makan hari ke 3 


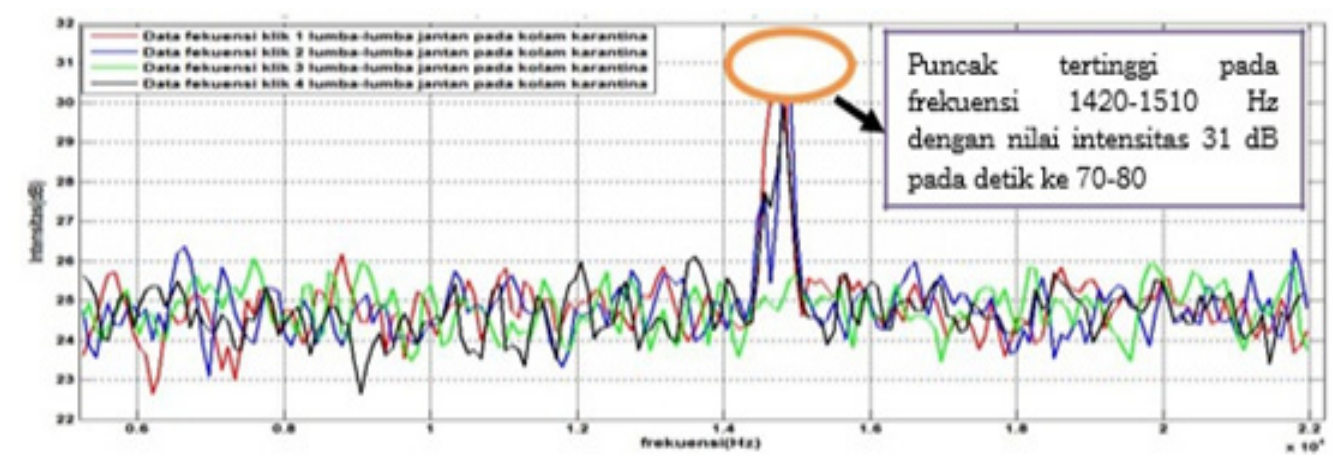

Gambar 13. Hubungan frekuensi terhadap intensitas sesudah makan hari ke 3

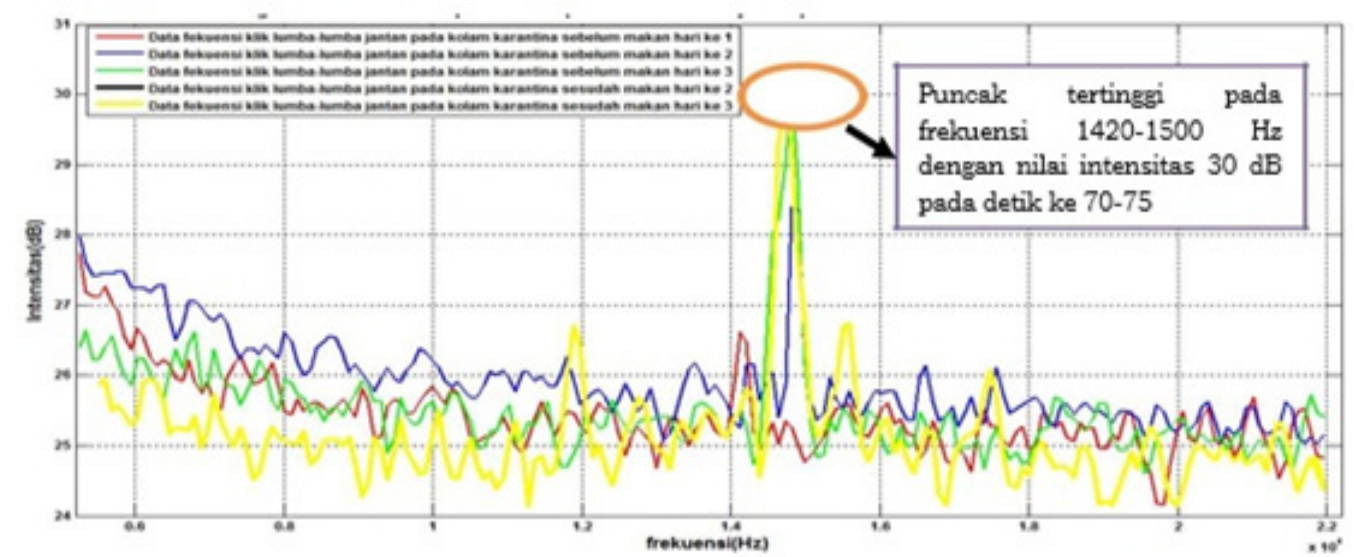

Gambar 14. Hubungan frekuensi terhadap intensitas sebelum makan hari ke 1, 2, dan 3 serta sesudah makan hari ke 2 dan 3

\section{KESIMPULAN DAN SARAN}

Lumba-lumba jantan hidung botol yang dipelihara di Taman Safari Indonesia, Cisarua Bogor memiliki range frekuensi suara klik dengan nilai intensitas tertinggi yaitu sebesar $32 \mathrm{~dB}$ dengan suara klik 3 sesudah makan pada hari ke 2 yang terdapat pada range frekuensi yaitu 1.4001600 Hz. Frekuensi suara klik lumba-lumba jantan (Tursiop aduncus) di Taman Safari adalah yaitu pada frekuensi $1.400-1.500$ $\mathrm{Hz}$, mempunyai nilai intensitas terendah sebesar $28.03 \mathrm{~dB}$ dan tertinggi adalah sebesar $32.01 \mathrm{~dB}$.

\section{DAFTAR PUSTAKA}

Buckstaff KC. 2004. Effects of watercraft noise on the acoustic behavior of bottlenosedolphins, Tursiops truncatus, in Sarasota Bay, Florida. Marine Mammal Science 20:709- 725.

Caldwell MC, Caldwell DK, Tyack PL. 1990. Review of the signaturewhistle hypothesis for the Atlantic bottlenose dolphin. Pages 199-234 in S. Leatherwood and R. R. Reeves, eds. The bottlenose dolphin. Academic Press, New York, NY.

Cook MLH, Sayigh LS, Blum JE, Wells RS. 2004. Signature whistle production in undisturbed free-ranging bottlenose dolphins (Tursiops truncatus). Proceedings of the Royal Society, Series B271;1043-1049.

Dolphin Theraphy Center Kas. 2006. h t t p : / / www.sharazan.de / Delfintherapie/english/therapycentre. htm\#physiotherapie [6 Juni 2015 Pukul 13.05 WIB].

Potts D, Steidl G, Tasche M. 2001. Fast Fourier transforms for nonequispaced data: a tutorial, in: J.J. Benedetto, P.J.S.G. Ferreira (Eds.), Modern Sampling Theory: Mathematics and Applications, Boston.

Finneran JJ. 2003. Whole-lung resonance in a bottlenose dolphin (Tursiops truncatus) and a white whale (Delphinapterus leucas). Journal of the Acoustical Society of America, 114, 529-535.

Finneran JJ, Houser DS. 2006. Comparison of in air evoked potential and underwater behavioral hearing 
thresholds in four bottlenose dolphins (Tursiops truncatus). Journal of the Acoustical Society of America, 119, 3181-3192.

Cranch GA, Nash PJ, Kirkendall CK. 2003. "Large-scale remotely interrogated arrays of fiber-optic interferometric sensors for underwater acoustic applications," IEEE Sensors Journal, vol. 3, pp. 19-30.

Janik VM, Slater PJ. 1998. Context-specific use suggests that bottlenose dolphin signature whistles are cohesion calls, Animal Behav. 56, 829-838.

Marshall CD. 2002. Morphology in encyclopedia of marine mammals. W.F. Perrin, B. Wursig and J.G.M. Thewissen (eds.). Academic Press, San Diego. p770-773.

Pratt M. 1998. Better angling with simple science: The White Friars Press. London.

Read AJ, Urian, Wilson KWB. Waples DM. 2003. Abundance of bottlenose dolphins in the bays, sounds and esturies of North Carolina. Mar. Mammal Sci. 19(1):59-73.
Sayigh LS, Tyack PL, Wells RS, Scott MD. 1990. Signature whistles of freeranging bottlenose dolphins, Tursiops truncatus: Stability and motheroffspring comparisons. Behavioral Ecology and Sociobiology

Simmonds J, MacLennan D. 2005. Fisheries acoustics: theory and practice, second edition. Blackwell.

Urick, R.J. 1975. Principles of underwater sound. Kingsport Press,

Wartzok D, Ketten DR. 1999. Marine mammal sensory systems. In J. E. Reynolds II \& S. A. Rommel (Eds.), Biology of marine mammals (pp. 117-175).Washington, DC: Smithsonian Institution Press

Watkins WA, Wartzok D. 1985 Sensory biophysics of marine mammals. Mar. Mam. Sci. 1(3), 219- 260.

www.mathworks.com (diakses tanggal 16 Mei 2015).

www.seaworld.org (diakses tanggal 16 Mei 2015).

www.steinberg.net (diakses tanggal 16 Mei 2015). 